\title{
Phylogeny of the genus Percus (Coleoptera: Carabidae) - nuclear genes and the basal splits
}

\author{
Martina Brückner \& Dietrich Mossakowski
}

\begin{abstract}
Brückner, M. \& Mossakowski, D. 2006: Phylogeny of the genus Percus (Coleoptera: Carabidae) - nuclear genes and the basal splits. - Entomol. Fennica 17: 195-199.
\end{abstract}

The phylogeny of the western Mediterranean genus Percus s.l. (Coleoptera, Carabidae) was analysed using partial DNA sequences of the nuclear 28S rRNA gene ( $865 \mathrm{bp}$ ). All 18 species of Percus s.l. with exception of $P$. espagnoli from the Balearic Islands were included. Phylogenetic analysis using the Maximum likelihood method reveals that the genus splits into three groups. The French Percus villai stands on its own. The Tyrrhenian species of Corsica, Sardinia, Sicily and the Italian mainland form the second group. Within this group, the phylogenetic relationships are not resolved. The third group includes Percus plicatus from Mallorca and the species of the subgenus Pseudopercus from the Iberian Peninsula. These results indicate that the subgenus Percus s.str. is paraphyletic. The split of Pseudopercus and P. plicatus probably occurred with the separation of the Balearic islands from the Iberian peninsula (20 million years ago) or by the flooding of the Mediterranean after the Messinian salinity crisis (5.3 million years ago). Based on these assumptions, the divergence rate of the $28 \mathrm{~S}$ gene can be estimated as being at $0.22-0.27 \%$ or at $0.99-1.01 \%$ per million years.

M. Brückner and D. Mossakowski, Institute of Ecology and Evolutionary Biology, University of Bremen, P. O. Box 330 440, D-28334 Bremen, Germany; email:martina@uni-bremen.de

Received 7 December 2005, accepted 08 June 2006

\section{Introduction}

The genus Percus s.l. (Coleoptera: Carabidae) consists of 18 species which are distributed in the western Mediterranean area (Fig. 1). Traditionally this genus was divided into two subgenera, Percus s.str. and Pseudopercus. The 14 species of Percus s.str. are distributed around the Tyrrhenian Sea (Corsica, Sardinia, Sicily and the Italian mainland), in the French Maritime Alps (Percus villai) and in the Balearic Islands (P. plicatus in Mallorca and Menorca and $P$. espagnoli in Cabrera and Foradada). The subgenus Pseudo- percus consists of four species which are distributed in the south-eastern part of the Iberian Peninsula.

The distinction between Pseudopercus and Percus s.str. is based mainly on the keel at the $7^{\text {th }}$ interstriae which is more distinct in Percus s.str. than in Pseudopercus (Lagar Mascaro 1965). Ganglbauer (1909) and Porta (1923) divided the Percus species using the series umbilicata at the $8^{\text {th }}$ interstriae which is missing in Pseudopercus and in P. strictus, P. grandicollis and P. cylindricus. Enlarged and transversally furrowed temples are present in P. strictus, $P$. grandicollis and 


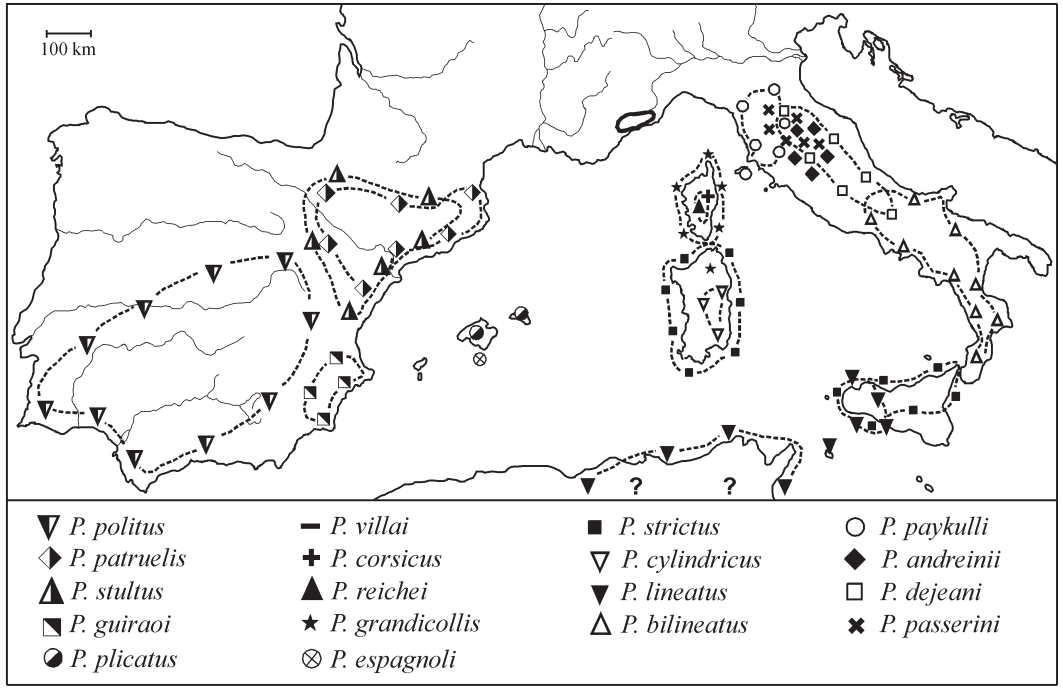

Fig. 1. Distribution of the Percus s.l. species; modified after Lagar Mascaro (1965) and Casale \& Vigna Taglianti (1982).
P. corsicus. Ganglbauer (1909) described a close ("sehr nahe") relationship of $P$. passerini, $P$. villai, $P$. lineatus and $P$. bilineatus which all show striae on the elytra. However, a morphologic analysis of the genus Percus s.l. based on the principles of Phylogenetic Systematics is missing up to now.

A detailed analysis of the species complex of P. strictus and P. grandicollis was performed by Brückner (2001, 2002a) using mtDNA sequences of protein coding genes, RAPD and morphometric data. An allozyme analysis of $P$. strictus from Sardinia was performed by Ketmaier et al. (2003). Phylogenetic analyses of the Pseudopercus species based on mitochondrial and nuclear DNA sequences lead to different gene trees which must be the result of ancestral polymorphism or introgression (Brückner 2004). A detailed phylogenetic and biogeographic analysis was performed by Brückner (2002b). In the present study, the monophyly of the two subgenera and the phylogeny of the basal groups are analysed using nuclear gene sequences.

DNA sequences of slow evolving nuclear genes like the 28S rRNA gene seem to be suitable especially to resolve deep branches and older splits in carabids, since this gene has been successfully used for phylogenetic analyses in insects and especially in carabids before (Friedrich \& Tautz 1995, 1997, Kim et al. 2000). In Pseudopercus species, the 28S rRNA gene evolves 2-3 times slower than mitochondrial genes (Brückner
2004). A further advantage of nuclear rRNA genes is their concerted evolution (Zimmer et al. 1980). The intraspecific variability of this gene is low, so phylogenetic analyses can be performed with only few individuals of each species for an appropriate phylogenetic reconstruction (e.g., Hillis \& Dixon 1991).

\section{Material and methods}

DNA sequences of all species of the genus Percus s.l. (except for Percus espagnoli) from the following collection sites were analysed: $P$. passerini (Dejean, 1828) (Tuscany, Italy), P. paykulli Rossi, 1790 (Tuscany, Italy), P. andreinii Mainardi, 1914 (Umbria, Italy), P. dejeani Dejean, 1831 (Lazio and Marche, Italy), P. bilineatus (Dejean, 1828) (Calabria, Italy), P. reichei Kraatz, 1858 (Corsica, France), P. corsicus Serville, 1820 (Corsica, France), P. grandicollis Serville, 1820 (Corsica, France), P. strictus Dejean, 1828 (Sardinia and Sicily, Italy) and P. cylindricus Chaudoir, 1868 (Sardinia, Italy). DNA sequences are deposited in the GenBank data base under accession numbers DQ789060 DQ789074. The following sequences (Acc. No. AY334311-AY334317) were obtained from a previous study (Brückner 2004): Percus villai Kraatz, 1858 (Maritime Alps, France), P. lineatus Solier, 1835 (Sicily, Italy), P. plicatus (Dejean, 1828) (Mallorca, Spain), Pseudopercus politus 


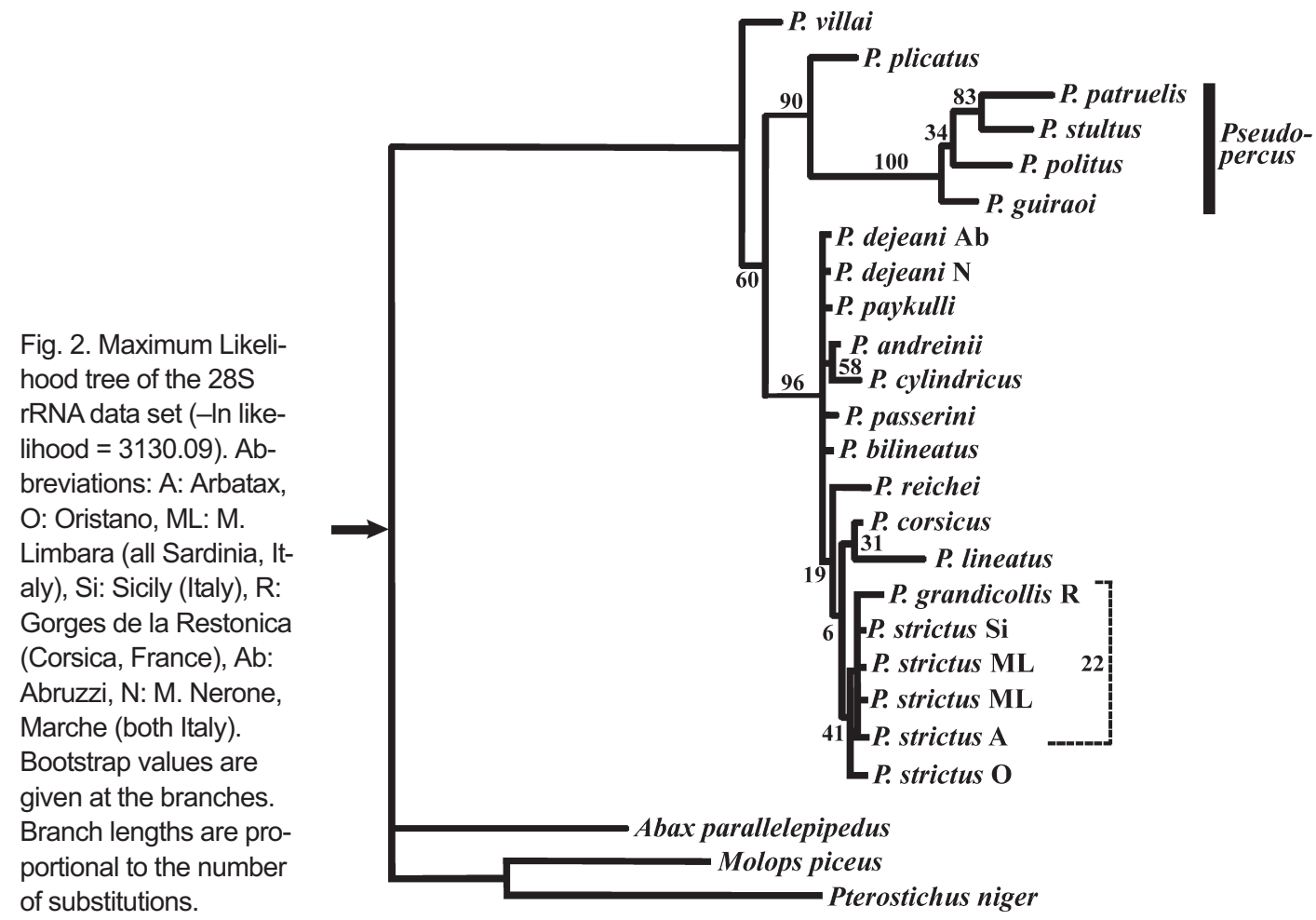

(Dejean, 1831) (Andalusia, Spain), Pseudopercus patruelis Dufour, 1820 (Girona, Spain), Pseudopercus guiraoi Perez-Arcas, 1869 (Murcia, Spain) and Pseudopercus stultus Dufour, 1820 (Castellón, Spain).

DNA was isolated from thoracic muscle of frozen specimen using the QIAamp tissue kit (Qiagen). The amplification of the analysed part of the 28S rRNA gene (approx. 1,000 basepairs) was performed using the primers $28 \mathrm{~S}-01$ and 28SR-01 (Kim et al. 2000) (PCR cycles: $5 \mathrm{~min}$ $96{ }^{\circ} \mathrm{C}(1 \mathrm{x}) ; 90 \mathrm{sec} 96{ }^{\circ} \mathrm{C}, 90 \mathrm{sec} 46^{\circ} \mathrm{C}, 90 \mathrm{sec}$ $68^{\circ} \mathrm{C}(5 \mathrm{x}) ; 90 \sec 96{ }^{\circ} \mathrm{C}, 90 \sec 50{ }^{\circ} \mathrm{C}, 90 \mathrm{sec}$ $\left.68^{\circ} \mathrm{C}(28 \mathrm{x}) ; 3 \min 68^{\circ} \mathrm{C}\right)$. After separation on an agarose gel and a cleaning step using the Qiaex II gel extraction Kit (Qiagen), DNA sequencing of the PCR product was done on an ABI 373A sequencer using the PCR primers. In addition, two internal primers were designed for sequencing (28S-i: 5'-GTT TAC CCC TGA ACA GTT TCA CG-3'; 28S-ir: 5'-GTG AAA CTG TTC AGG GGT AAA CC-3').

For alignment the ClustalX program (Thompson et al. 1997) was used (gap opening: 10; delay sequence divergence: $40 \%$; DNA transition weight: 0.5). Gaps and parts of uncertain homology were removed from the data set. Homoplasy content was checked using transition-transversion ratio and skewness. Phylogenetic analysis was performed using the Maximum Likelihood (ML) algorithm in PAUP* 4.0b10 (Swofford 1998). The HKY85 evolution model with empirical base frequencies and observed transition/transversion ratio was chosen for the analysis.

Branch support was checked by bootstrap analysis (1,000 pseudoreplicates). Two further Molopini, viz. Abax parallelepipedus and $\mathrm{Mo}$ lops piceus, and one Pterostichini, viz. Pterostichus niger, were chosen as out-group species for the present analysis.

\section{Results}

After removing gaps and parts of uncertain homology, the 28S rRNA data matrix consists of 865 positions in 25 taxa. The $28 \mathrm{~S}$ rRNA gene GC content $(42.4 \%)$ is much higher than in insect mitochondrial genes. The data set of the in-group 
contains 107 variable and 57 phylogenetically informative sites. The highest observed $\mathrm{p}$-distance within the in-group is $7.13 \%$ ( $P$. patruelis and $P$. cylindricus). The mean p-distance is $2.78 \%$ within the in-group. The high transition-transversion ratio (1.73) and the low $g_{1}$ value (-1.56) indicate a low homoplasy content in the $28 \mathrm{~S}$ rRNA data set so that the phylogenetic results are probably based on synapomorphic characters.

The phylogenetic analysis of the 28S rDNA sequences resulted in the Maximum Likelihood tree shown in Fig. 2. Three groups are found: Percus villai stands on its own. The Tyrrhenian species form a second group, supported by $96 \%$ bootstrap value. The Spanish Pseudopercus species and Percus plicatus from the Balearic Islands build up the third group which is supported by $90 \%$ bootstrap value. Considering these three groups $P$. villai splits first.

\section{Discussion}

The basal split between $P$. villai and all other investigated in-group species is only weakly supported. A bootstrap value of $60 \%$ is too low to discuss this basal split as the most ancient speciation process occurred in the genus Percus s.l. Therefore, the relationship of the three major groups remains unresolved.

The Tyrrhenian group is supported by the high bootstrap value of $96 \%$. However, the splits within this monophyletic group are much more recent than the other splits because of the very short branch lengths. Therefore, no resolution is found using the slowly evolving $28 \mathrm{~S}$ rDNA sequences. Other genes with higher substitution rates such as mitochondrial genes are more successful in resolving these relationships (Brückner 2002).

The four Pseudopercus species form a monophyletic group which is supported by a $100 \%$ bootstrap value. This subgenus is sister to P. plicatus (subgenus Percus) from Mallorca with a 90\% bootstrap support. This split between P. plicatus and the ancestor of the Pseudopercus species was probably caused by the separation of the Balearic Islands from the Iberian Peninsula which was dated back to approx. 20 myr ago (Rögl \& Steininger 1983). Alternatively, this split could have happened at the end of the Messinian (5.3 million years ago) when the Mediterranean was flooded again after a period of drying (Hsü et al. 1977). The observed genetic distances (percentage of divergence) of the 28S DNA sequences between P. plicatus and Pseudopercus are $4.32-5.36 \%$. Based on these data and assuming a constant substitution rate at each branch, the divergence rate of the $28 \mathrm{~S}$ gene can be calculated at $0.22-0.27 \%$ or at $0.99-1.01 \%$ per million years.

The positioning of $P$. plicatus together with Pseudopercus indicates that the subgenus Percus s.str. is not monophyletic and it is divided in the three major groups mentioned above. The main morphological character which differentiates the two subgenera is the keel at the basis of the $7^{\text {th }}$ interstriae which is more distinct in Percus s.str. than in Pseudopercus. The phylogenetic results indicate that the distinct keel of the Percus s.str. species is the plesiomorphic character state within Percus s.l. Within the other Molopini, the genus Abax shows a distinct keel, but Molops does not. So the interpretation of the distinct keel as the apomorphic or plesiomorphic character state of the Molopini is difficult. Following the result of a phylogenetic analysis of the genera Abax, Molops and Percus which resulted in a sistergroup relationship of Abax and Molops (Düring \& Brückner 2000), the keel of Abax and Percus can be interpreted as convergent. The other possibility is that the keel is the plesiomorphic character state within the Molopini and has been lost in Molops. Other traits like the shape of pronotum, the basal fovea of the pronotum and the form of the elytrae are not very well suited for differentiation of the two subgenera because of the high morphologic variability within some Percus s.str. species, e.g., in P. strictus.

In conclusion, the division of Percus s.l. into two monophyletic subgenera is refuted.

Further investigations using morphological characters of the paraphyletic Percus s.str. species should lead to a revision of the genus.

Acknowledgements. We would like to thank P. Brandmayr, K. Desender, A. Düring, J. Galián, B. Klein, H. Knitter, J.C. Malausa, M. Marciniak, A. Ortiz, F. Prüser and J. Serrano for providing beetle specimens, and A. Düring for helpful discussion. 


\section{References}

Brückner, M. 2001: Inter- and Intrapopulation Differentiation in Percus strictus and Percus grandicollis RAPD-Analysis in two closely related carabid species. - Mitt. Dtsch. Ges. Allg. Angew. Ent. 13: 95100.

Brückner, M. 2002a: Out of Sardinia - Cladistic biogeographic analysis of Percus strictus and Percus grandicollis. - In: Szyszko, J. et al. (eds.), How to protect or What we know about Carabid Beetles, X European Carabidologists Meeting, Tuczno 2001, Poland: 321329. Warsaw Agricultural Press.

Brückner, M. 2002b: Phylogenie und Biogeographie der Gattung Percus Bonelli 1810 (Coleoptera, Carabidae): Eine molekularsystematische Analyse. Academic thesis, University of Bremen. 245 pp.

Brückner, M. 2004: The phylogeny of the subgenus Pseudopercus (Coleoptera, Carabidae): Conflicts between mitochondrial and nuclear DNA sequences. Mitt. Dtsch. Ges. Allg. Angew. Ent. 14: 77-82.

Casale, A. \& Vigna Taglianti, A. 1982: I Coleotteri Carabidi delle Alpi Liguri: composizione della fauna ed origine del popolamento. — Lavori della Societa' Italiana di Biogeografia 9: 567-598. [In Italian.]

Düring, A. 2004: Molekularsystematische Untersuchungen am Carabidentaxon Abax Bonelli 1810 (Coleoptera, Carabidae). - Academic thesis, University of Bremen. 363 pp.

Düring, A. \& Brückner, M. 2000: The evolutionary history of the tribe Molopini: A first molecular approach. In: Brandmayr, P. et al. (eds.), Natural History and Applied Ecology of Carabid Beetles - Proceedings of the IX European Carabidologists' Meeting (26-31 July 1998, Camigliatello, Cosenza, Italy): 1-4. Pensoft, Sofia, Moskow.

Friedrich, M. \& Tautz, D. 1995: Ribosomal DNA phylogeny of the major extant arthropod classes and the evolution of myriapods. - Nature 376: 165-167.

Friedrich, M. \& Tautz, D. 1997: Evolution and phylogeny of the Diptera: A molecular phylogenetic analysis using 28S rDNA sequences. — Syst. Biol. 46 (4): 674 698.

Ganglbauer, L. 1909: Percus-Studien. — Deutsch. Ent. Zeitschr. 1: 97-105.
Hillis, D. M. \& Dixon, M. T. 1991: Ribosomal DNA: Molecular evolution and phylogenetic inference. - The Quarterly Review of Biology 66 (4): 411-453.

Hsü, K. J., Montadert, L., Bernoulli, D., Cita, M. B., Erickson, A., Garrison, R. E., Kidd, R. B., Mèlierés, F., Müller, C. \& Wright, R. 1977: History of the Mediterranean salinity crisis. - Nature 267: 399-403.

Ketmaier, V., Casale, A., Cobolli, M., de Matthaeis, E. \& Vigna Taglianti, A. 2003: Biochemical systematics and phylogeography of the Percus strictus subspecies (Coleoptera, Carabidae), endemic to Sardinia. - Ital. J. Zool. 70: 339-346.

Kim, C.-G., Zhou, H.-Z., Imura, Y., Tominaga, O., Su, Z.H. \& Osawa, S. 2000: Pattern of morphological diversification in the Leptocarabus ground beetles (Coleoptera: Carabidae) as deduced from mitochondrial ND5 gene and 28S rDNA sequences. - Mol. Biol. Evol. 17(1): 137-145.

Lagar Mascaro, A. 1965: Revisión de las especies iberobaleares del genero "Percus" Bonelli ("Coleoptera Pterostichidae"). — Miscelanea Zoologica 21: 79-88. [In Spanish.]

Nei, M. \& Kumar, S. 2000: Molecular evolution and phylogenetics. - Oxford University Press, New York. 333 pp.

Porta, A. 1923: Fauna Coleopterorum Italica Vol. I Adephaga. - Stabilimento Tipografico Piacentino, Piacenza. [In Italian.]

Rögl, F. \& Steininger, F. F. 1983: Vom Zerfall der Tethys zu Mediterran und Paratethys. - Ann. Naturhist. Mus. Wien 85 A: 135-163.

Swofford, D. L. 1998: PAUP*. Phylogenetic Analysis Using Parsimony (*and other methods), Version 4. Sinauer Associates, Sunderland, Massachusetts.

Thompson, J. D., Gibson, T. J., Plewniak, F., Jeanmougin, F. \& Higgins, D. G. 1997: The ClustalX windows interface: flexible strategies for multiple sequence alignment aided by quality analysis tools. - Nucleic Acids Res. 24: 4876-4882.

Zimmer, E. A., Martin, S. L., Beverley, S. M., Kan, Y. W. \& Wilson, A. C. 1980: Rapid duplication and loss of genes coding for the a chains of hemoglobin. — Proc. Natl. Acad. Sci. USA 77 (4): 2158-2162. 